\title{
KAJIAN AWAL PEMBUATAN FILM PLASTIK (BAHAN PLASTIK PENGEMAS) DARI PATI BATANG UBI KAYU
}

\author{
Harrison Situmorang, M. Hendra S. Ginting \\ Departemen Teknik Kimia, Fakultas Teknik, Universitas Sumatera Utara \\ Jl. Almamater Kampus USU Medan 20155, Indonesia \\ Email: harrison.stmr@gmail.com
}

\begin{abstract}
Abstrak
Film plastik pati dibuat dari pati batang ubi kayu dengan menggunakan gliserol sebagai pemlastis dan asam asetat sebagai katalis yang digelatinasi pada suhu $75^{\circ} \mathrm{C}$ selama 15 menit. Berat pati, volume air, volume gliserol, dan volume asam asetat divariasikan. Hasil analisa kekuatan tarik dan pemanjangan saat putus menunjukkan bahwa variasi volume asam asetat $3 \mathrm{ml}(3: 10 \mathrm{w} / \mathrm{w})$ dan variasi volume gliserol $2 \mathrm{ml}(1: 4 \mathrm{w} / \mathrm{w})$ merupakan kondisi variasi terbaik. Sementara pada variasi volume air, nilai kekuatan tarik berbanding terbalik dengan pemanjangan saat putus. Pada analisa FTIR ditemukan bahwa spectrum $\alpha-1,6$ glikosidik $\left(1010 \mathrm{~cm}^{-1}\right)$ menghilang sebagai efek kehadiran asam asetat, sementara spektrum $\alpha-1,4$ glikosidik, $\mathrm{C}-\mathrm{O}-\mathrm{H}, \mathrm{C}=\mathrm{O}$, dan $\mathrm{OH}$ bergeser sebagai efek dari proses plastisasi.
\end{abstract}

Kata kunci : pati batang ubi kayu, gliserol, asam asetat, termoplastik pati

\begin{abstract}
Starch plastic films made from cassava stem starch by using glycerol as plasticizer and acetic acid as a catalyst gelatinized at $75{ }^{\circ} \mathrm{C}$ for 15 minutes. Starch weight, water volume, glycerol volume, and acetic acid volume were varied. The variation conditions of $3 \mathrm{ml}$ of acetic acid volume $(3: 10 \mathrm{w} / \mathrm{w})$ and $2 \mathrm{ml}$ of glycerol volume $(1: 4 \mathrm{w} / \mathrm{w})$ gave the best of tensile strength and elongation at break analysis. While at water volume variation, the tensile strength value is inversely proportional to the elongation at break. In FTIR analysis found that $\alpha-1,6$ glycosidic $\left(1010 \mathrm{~cm}^{-1}\right)$ spectrum disappears as the effect of acetic acid presence, while the spectrum of $\alpha-1,4$ glycosidic, $\mathrm{COH}, \mathrm{C}=\mathrm{O}$, and $\mathrm{OH}$ shifted as the plasticization effect.
\end{abstract}

Keywords: cassava stems starch, glycerol, acetic acid, thermoplastic starch

\section{Pendahuluan}

Ada sekitar 34 juta ton plastik per tahun diproduksi oleh industri plastik dunia dan sekitar $40 \%$ nya dibuang ke tempat penimbunan sampah yang kapasitasnya juga terbatas. Sementara itu kebutuhan plastik 220 juta penduduk Indonesia pada tahun 2003 mencapai sekitar 35 juta ton sedangkan kemampuan pemerintah mengolah sampah hanya $20-30 \%$ [7]. Sejalan dengan itu, upaya untuk mengurangi pembuangan produk plastik dan meningkatkan kesadaran masyarakat akan kualitas lingkungan, maka perlu dicari bahan baku plastik alternatif yang dapat terurai secara alami oleh lingkungan.

Ubi kayu merupakan bahan baku alami untuk membuat film plastik. Hal ini dapat menjadi solusi permasalahan lingkungan sekaligus produk alternatif pengganti plastik sintetik yang berbahan baku petrokimia. Oleh karena itu pemanfaatan bahan baku ubi kayu dapat menyaingi keberadaan plastik sintesis. Terlebih lagi plastik kemasan makanan yang sangat beresiko dengan aspek kesehatan.
Peneliti terdahulu mengenai plastik biodegradabel dari ubi kayu telah banyak dilakukan, namun belum ada peneliti yang memanfaatkan pati dari batang ubi kayu sebagai bahan baku dalam pembuatan film plastik. Oleh karena itu penelitian ini dilakukan untuk membuat film plastik dari pati batang ubi kayu sebagai bahan dasar pembuatan film plastik.

\section{Teori}

Pati adalah polimer semi-kristal yang tidak akan melebur secara tradisional menjadi fasa cair. Kristal pati mengandung 9-10\% w/w kandungan air. Karakteristik unik yang dimiliki oleh pati adalah sifat proses termalnya lebih kompleks dari polimer konvensional karena banyaknya reaksi fisika dan reaksi kimia yang terlibat sepanjang proses.

Contoh fenomena yang terjadi selama proses berlangsung seperti : difusi air, pembesaran granula, gelatinasi, dekomposisi, mendidih, dan mengkristal. Mengkristal merupakan bagian terpenting, karena proses inilah yang menunjukkan konversi pati menjadi thermolastik [1]. Pati 
merupakan homopolimer glukosa dengan ikatan $\alpha$-glikosidik. Pati terdiri dari dua fraksi yang dapat dipisahkan dengan air panas. Fraksi terlarut disebut amilosa dan fraksi tidak larut disebut amilopektin. Struktur amilosa merupakan struktur lurus dengan ikatan $\alpha$-(1,4)-glikosidik. Amilopektin terdiri dari struktur bercabang dengan ikatan $\alpha$-(1,4)-glikosidik dan titik percabangan amilopektin merupakan ikatan $\alpha$ $(1,6)$ glikosidik [4].

\section{Metodologi Penelitian \\ Bahan dan Alat}

Bahan yang digunakan adalah batang ubi kayu, asam asetat, gliserol, air, dan $\mathrm{NaOH}$. Alat utama yang digunakan adalah beaker glass sebagai wadah pembuatan film plastik, kaca akrilik sebagai cetakan film plastik, dan timbangan digital untuk mengukur massa pati dan film plastik.

Pembuatan Film Plastik (bahan plastik pengemas) dari pati batang ubi kayu

Masukkan 10 gr serbuk pati ubi kayu, 25 $\mathrm{ml}$ air, dan $3 \mathrm{ml} \mathrm{CH}_{3} \mathrm{COOH}$ glasial ke dalam beaker gelas. Diaduk sampai homogen, lalu ditambahkan gliserol sebanyak $2 \mathrm{ml}$ dan diaduk lagi. Larutan kemudian dipanaskan pada hot plate dengan suhu $75^{\circ} \mathrm{C}$ selama 15 menit. Untuk menghindari keasaman pada gelatin yang terbentuk ditambahkan $\mathrm{NaOH} 0,1 \mathrm{M}$ hingga $\mathrm{pH}$ gelatin netral. Gelatin dituang ke dalam cetakan dan dikeringkan di bawah sinar matahari.

\section{Hasil dan Pembahasan}

Pengaruh berat pati terhadap sifat kekuatan tarik $\left(\sigma_{\mathrm{T}}\right)$ dan pemanjangan saat putus $(\varepsilon)$ film plastik

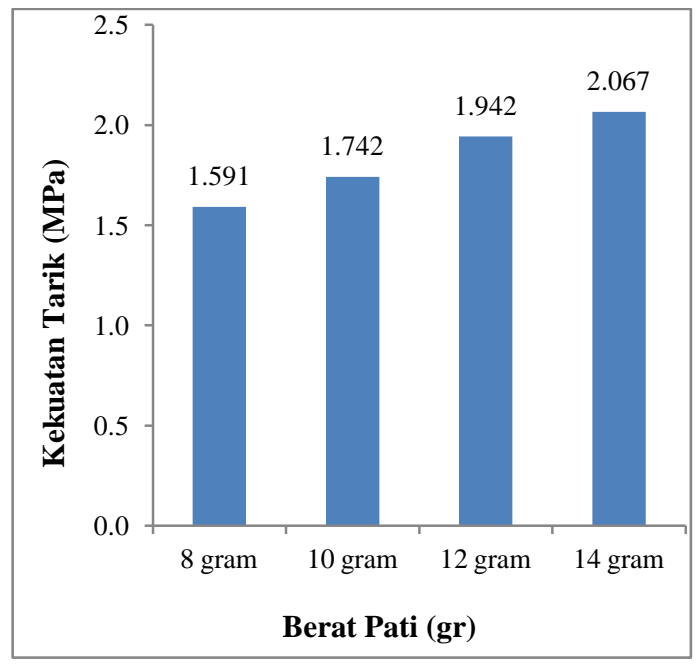

Gambar 1. Pengaruh Berat Pati terhadap Kekuatan Tarik Film Plastik
Pengaruh berat pati terhadap sifat kekuatan tarik film plastik terlihat pada gambar 1 . Pengaruh berat pati terhadap pemanjangan saat putus film plastik terlihat pada gambar 2 . Kekuatan tarik film plastik tertinggi diperoleh pada variasi berat pati 14 gr yaitu 2,067 MPa dan terendah pada variasi 8 gr pati yaitu sebesar 1,951 MPa. Nilai pemanjangan saat putus ratarata tertinggi diperoleh pada penambahan pati 8 gr yaitu 34,1 \%. Pertambahan berat pati mengakibatkan meningkatnya nilai kekuatan tarik film plastik dan menurunnya pemanjangan saat putus film plastik. Hal ini disebabkan pada konsentrasi yang tinggi, pati batang ubi kayu sebagai penyusun film plastik dibentuk semakin banyak berikatan sehingga menyebabkan plastik semakin kuat, akan tetapi perbandingan $\%$ berat air, gliserol dan asam asetat semakin kecil yang mengakibatkan pemanjangan saat putus film plastik rendah [5].

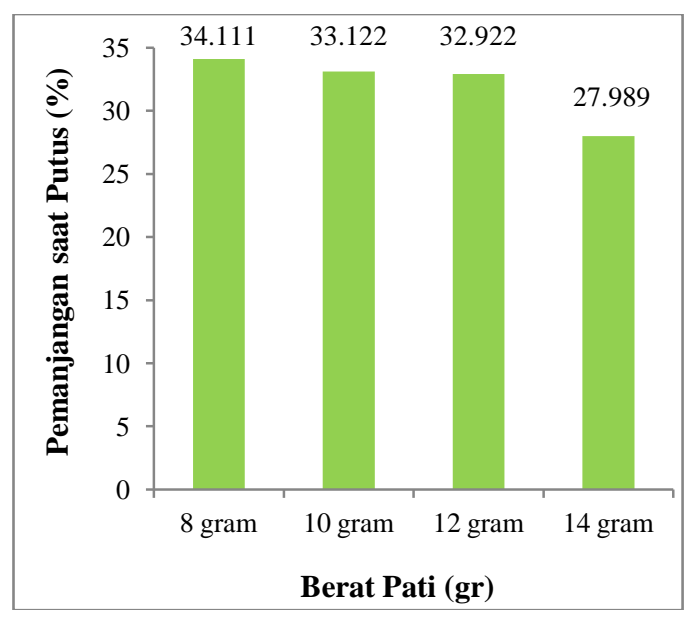

Gambar 2. Pengaruh Berat Pati terhadap Pemanjangan Saat Putus Film Plastik

Pengaruh volume air terhadap sifat kekuatan tarik $\left(\sigma_{\mathrm{T}}\right)$ dan pemanjangan saat putus $(\varepsilon)$ film plastik

Pengaruh volume air terhadap sifat kekuatan tarik film plastik terlihat pada gambar 3 . Pengaruh volume air terhadap pemanjangan saat putus film plastik terlihat pada gambar 4. Kekuatan tarik film plastik tertinggi diperoleh pada variasi volume air $20 \mathrm{ml}$ yaitu $2,80 \mathrm{MPa}$ dan terendah pada $40 \mathrm{ml}$ air sebesar $0,88 \mathrm{MPa}$. Pemanjangan saat putus film plastik tertinggi diperoleh pada variasi volume air $40 \mathrm{ml}$ yaitu sebesar 37,45 \%. Bertambahnya volume air mengakibatkan menurunnya nilai kekuatan tarik film plastik dan meningkatnya pemanjangan saat putus film plastik. Hal ini disebabkan karena ikatan glikosidik plastik telah digantikan oleh ikatan hidrogen pada air yang kekuatannya lebih 
lemah sehingga menyebabkan menurunnya nilai kekuatan tarik film plastik, akan tetapi pemanjangan saat putus film plastik meningkat karena air juga berfungsi sebagai pemlastis [5].

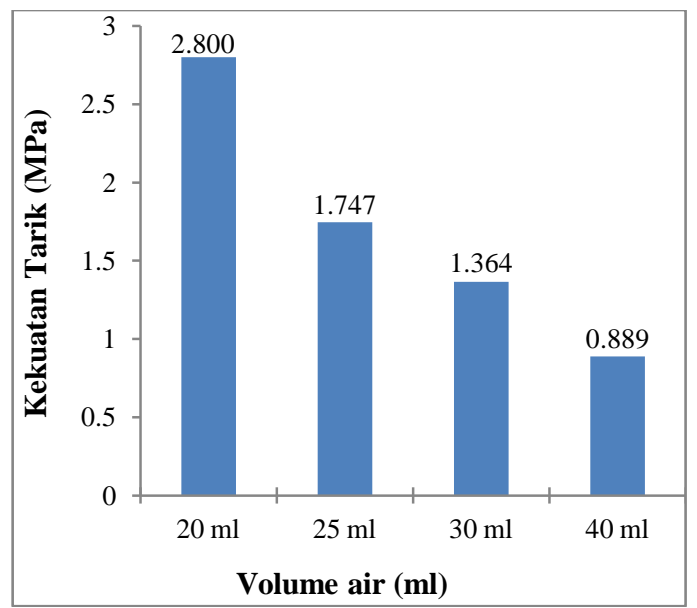

Gambar 3. Pengaruh volume air terhadap kekuatan tarik film plastik

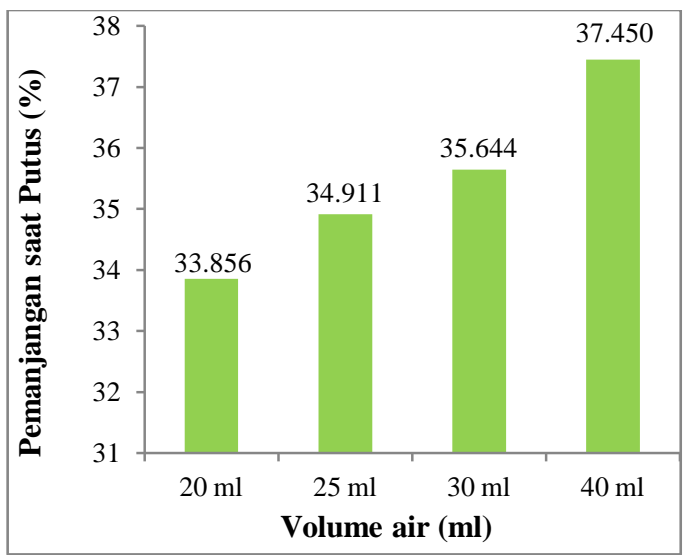

Gambar 4. Pengaruh Volume Air terhadap Pemanjangan Saat Putus Film Plastik

Pengaruh volume gliserol terhadap sifat kekuatan tarik $\left(\sigma_{\mathrm{T}}\right)$ dan pemanjangan saat putus ( $(\varepsilon)$ film plastik

Pengaruh volume air terhadap sifat kekuatan tarik film plastik terlihat pada gambar 5 . Pengaruh volume air terhadap pemanjangan saat putus film plastik terlihat pada gambar 6 . Kekuatan tarik film plastik tertinggi diperoleh pada variasi volume air $20 \mathrm{ml}$ yaitu $2,80 \mathrm{MPa}$ dan terendah pada $40 \mathrm{ml}$ air sebesar $0,88 \mathrm{MPa}$. Pemanjangan saat putus film plastik tertinggi diperoleh pada variasi volume air $40 \mathrm{ml}$ yaitu sebesar $37,45 \%$. Bertambahnya volume air mengakibatkan menurunnya nilai kekuatan tarik film plastik dan meningkatnya pemanjangan saat putus film plastik. Hal ini disebabkan karena ikatan glikosidik pada plastik mampu digantikan oleh air dengan ikatan hidrogen yang kekuatannya lebih lemah sehingga menyebabkan menurunnya nilai kekuatan tarik film plastik, akan tetapi air juga berfungsi sebagai pemlastis yang mengakibatkan pemanjangan saat putus film plastik meningkat. Hal yang sama juga ditunjukkan pada penelitian Leon Janssen, dkk yang menunjukkan bahwa semakin tinggi kandungan pati maka kekuatan tarik plastik akan semakin besar akan tetapi nilai pemanjangan saat putus film plastik tersebut akan semakin rendah karena rantai ikatan film plastik semakin renggang [5].

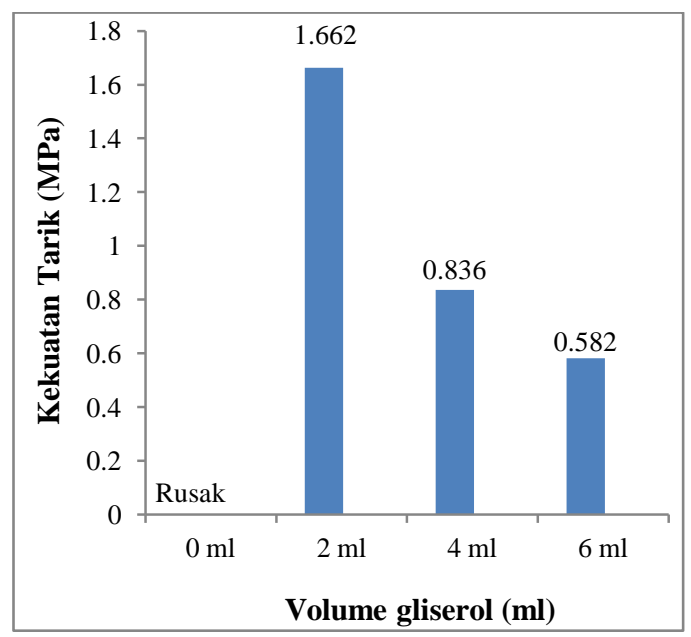

Gambar 5. Pengaruh Volume Gliserol terhadap Kekuatan Tarik Film Plastik

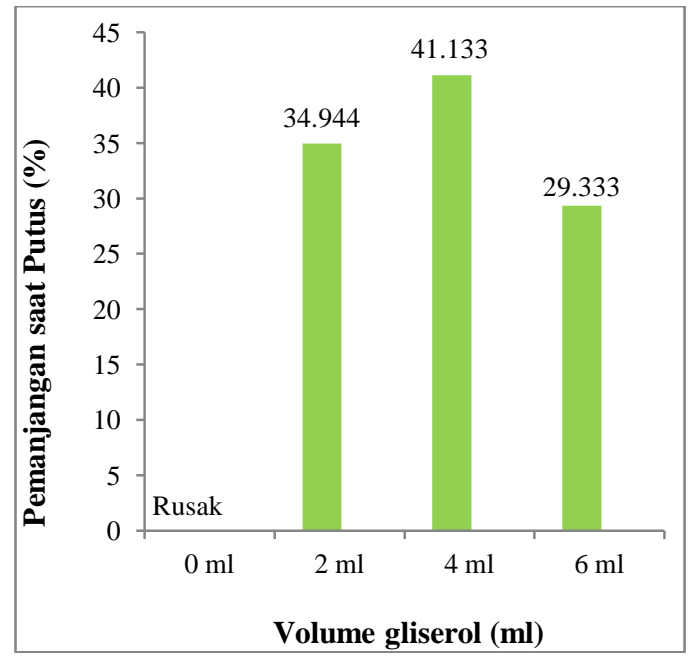

Gambar 6. Pengaruh Volume Gliserol terhadap Pemanjangan Saat Putus Film Plastik

Pengaruh volume asam asetat terhadap sifat kekuatan tarik $\left(\sigma_{\mathrm{T}}\right)$ dan pemanjangan saat putus $(\varepsilon)$ film plastik

Pengaruh volume asam asetat terhadap sifat kekuatan tarik film plastik terlihat pada 
gambar 7. Pengaruh volume asam asetat terhadap pemanjangan saat putus film plastik terlihat pada gambar 8 . Asam asetat berfungsi sebagai katalis yang memutuskan ikatan 1,4 glikosidik pada amilum dan 1,4 glikosidik serta 1,6 glikosidik pada amilopektin [8]. Kekuatan tarik film plastik tertinggi $(1,64 \mathrm{MPa})$ dan nilai pemanjangan saat putus tertinggi $(34,72 \%)$ diperoleh pada volume asam asetat $3 \mathrm{ml}$. Bertambahnya volume asam asetat hingga $3 \mathrm{ml}$ mengakibatkan meningkatnya nilai kekuatan tarik dan pemanjangan saat putus film plastik. Hal ini disebabkan karena semakin banyak volume asam asetat yang digunakan maka semakin banyak ikatan 1,6-glikosidik pada amilopektin yang terputus menghasilkan amilosa yang berikatan linier heliks.

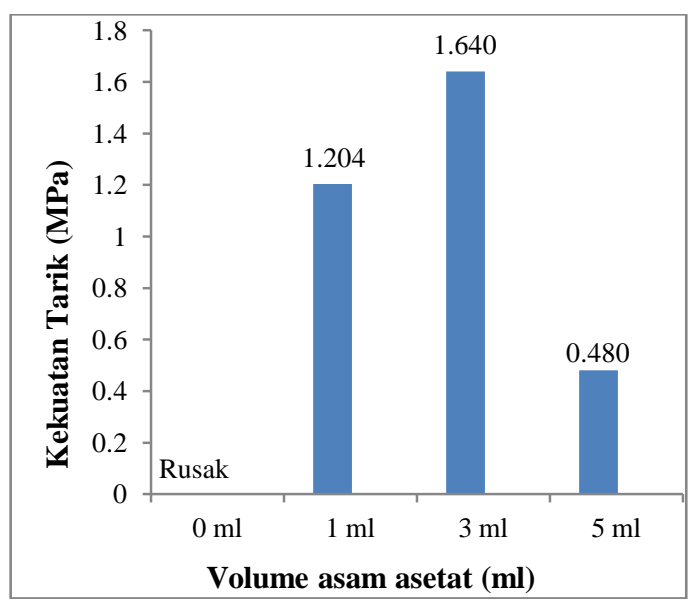

Gambar 7. Pengaruh Volume Asam Asetat terhadap Kekuatan Tarik Film Plastik

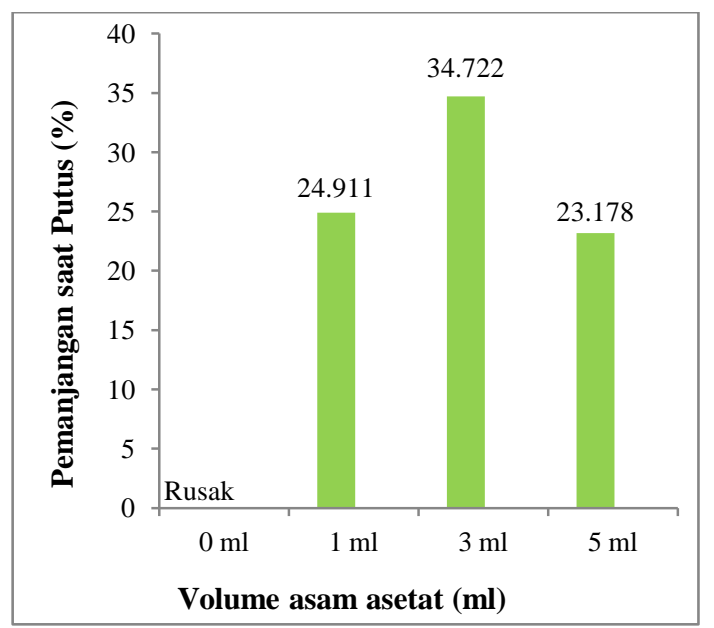

Gambar 8. Pengaruh Volume Asam Asetat terhadap Pemanjangan Saat Putus Film Plastik
Hal ini menyebabkan kekuatan tarik dari film plastik semakin besar karena semakin banyak amilum yang terbentuk [3], dan nilai pemanjangan saat putus dari film plastik tersebut juga semakin besar akibat formasi heliks pada amilum [2]. Jika penambahan volume asam asetat dilanjutkan lagi hingga $5 \mathrm{ml}$, kekuatan tarik dan pemanjangan saat putus film plastik menjadi menurun [2]. Hal ini disebabkan karena apabila ikatan percaba-ngan (1,6 glikosidik) telah habis, maka asam asetat justru akan memutus rantai linier (1,4 glikosidik) membentuk rantai heliks amilum yang lebih pendek [3].

\section{Analisa FTIR (Fourier Transform Infrared)}

Analisa ini bertujuan untuk mengetahui keberadaan gugus fungsi yang terdapat pada pati batang ubi kayu dan film plastik. Uji FTIR dilakukan dengan Shimadju IRPrestidge-21. Dengan tepung $\mathrm{KBr}$, spectra dilakukan sebanyak 45 pemindaian antara 4000-400 $\mathrm{cm}^{-1}$ dengan resolusi $16 \mathrm{~cm}^{-1}$. Kehadiran asam asetat menyebabkan putusnya rantai percabangan amilopektin yaitu gugus $\alpha-1,6$ glikosidik (1010 $\mathrm{cm}^{-1}$ ) pada film plastik, dan menyisakan rantai linier heliks amilum yang mempunyai gugus $\alpha$ 1,4 glikosidik $\left(1118 \mathrm{~cm}^{-1}\right)$. Kehadiran gliserol menyebabkan bergesernya spektrum gugus fungsi seperti $\mathrm{N}^{\wedge} \mathrm{H}\left(763 \mathrm{~cm}^{-1}\right.$ menjadi $\left.786 \mathrm{~cm}^{-1}\right)$, $\alpha-1,4$ glikosidik (1080 $\mathrm{cm}^{-1}$ menjadi $1118 \mathrm{~cm}^{-1}$ ), C-O-H (1149 $\mathrm{cm}^{-1}$ menjadi $\left.1172 \mathrm{~cm}^{-1}\right), \mathrm{C}=\mathrm{O}$ (1643 $\mathrm{cm}^{-1}$ menjadi $\left.1681 \mathrm{~cm}^{-1}\right), \mathrm{C}-\mathrm{H}\left(2931 \mathrm{~cm}^{-1}\right.$ menjadi $\left.2962 \mathrm{~cm}^{-1}\right)$, dan $\mathrm{OH}\left(3379 \mathrm{~cm}^{-1}\right.$ menjadi $3502 \mathrm{~cm}^{-1}$ ). Dalam pembuatan film plastik, terjadi proses kimia. Hal ini ditunjukkan dengan hilangnya gugus fungsi seperti $\mathrm{CH}_{2} \mathrm{OH}$ dan $\alpha-1,6$ glikosidik serta munculnya gugus baru seperti $\mathrm{CH}_{2}$, dan gugus $\mathrm{CH}_{n}[6]$. 


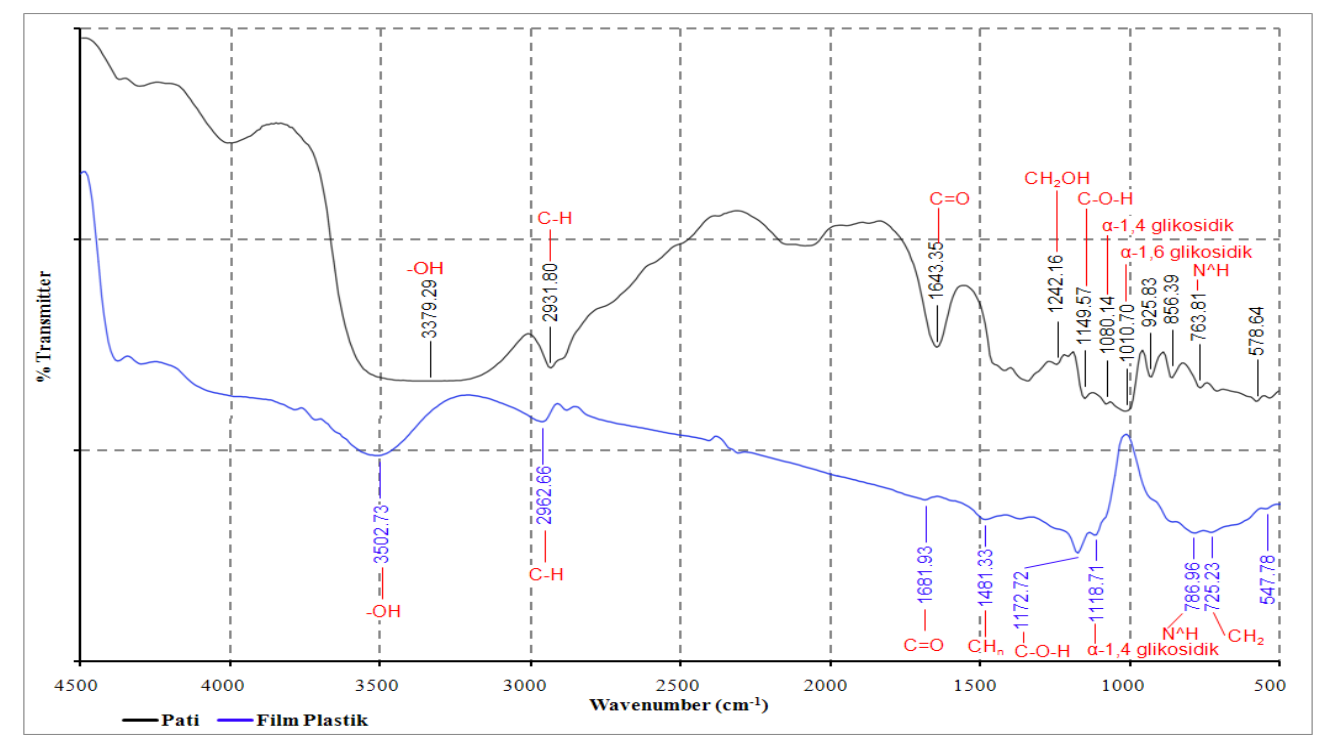

Gambar 9. Grafik Uji FT-IR Pati Batang Ubi Kayu dan Film Plastik

\section{Kesimpulan}

1. Semakin besar berat pati yang digunakan maka nilai kekuatan tarik dan daya serap air film plastik yang dihasilkan semakin besar, akan tetapi nilai pemanjangan saat putusnya semakin kecil.

2. Semakin banyak volume air yang digunakan maka nilai kekuatan tarik dan daya serap air film plastik yang dihasilkan semakin kecil, akan tetapi nilai pemanjangan saat putusnya semakin besar.

3. Kekuatan tarik maksimum (1,64 MPa) dan pemanjangan saat putus maksimum $(34,722 \%)$ diperoleh pada penambahan asam asetat $3 \mathrm{ml}(3: 10 \mathrm{w} / \mathrm{w})$, begitu juga daya serap air film plastik yang dihasilkan semakin besar seiring penambahan asam asetat.

4. Kekuatan tarik maksimum $(1,662 \mathrm{MPa})$ diperoleh pada penambahan gliserol sebanyak $2 \mathrm{ml}(1: 4 \mathrm{w} / \mathrm{w})$, akan tetapi pemanjangan saat putus maksimum $(41,133 \%)$ diperoleh pada penambahan gliserol $4 \mathrm{ml}(1: 2 \mathrm{w} / \mathrm{w})$, sementara daya serap air film plastik yang dihasilkan semakin besar seiring penambahan gliserol.

\section{Daftar Pustaka}

[1] Cui SW, Food Carbohydrates Chemistry Physical Properties and Application, Boca Raton, CRC Press, Taylor \& Francis Group, 2005, p.309-355.

[2] David K. Platt, Biodegradable Polymers Market Report, Rapra Technology, Shawbury, United Kingdom, 2006.

[3] James N. BeMiller, et al., Starch Chemistry and Technology (3rd ed.), Academic Press, p.511-539.
[4] Kellerhals, et al., Transcrystallization in Mcl-PHAs/Cellulose Whisker Composites, Macromolecules, 32, 1999, p.7396-7401.

[5] Leon Janssen et al., Thermoplastic Starch. Wiley-VCH Verlag GmbH \& Co. KGaA, Weinheim-Germany, 2009, p.305.

[6] Silverstein et al., Spectrometric Identification of Organic Compounds, 6th ed., John Wiley and Sons, New York, 1998.

[7] Syamsir, Plastik dari Senyawa Limonin, http://thekebun.wordpress.com, 2008, diakses pada 08 Oktober 2012.

[8] Yulia Gladyshko, Extraction of Hemicelluloses by Acid Catalyzed Hydrolysis, Saimaa University of Applied Sciences, Imatra, 2011. 